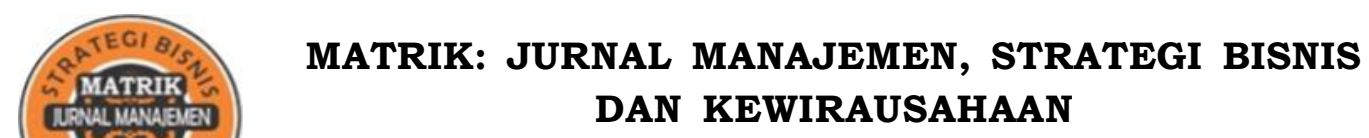

Homepage: https://ojs.unud.ac.id/index.php/jmbk/index

Vol. 13 No. 1, Februari 2019, 15-25

P-ISSN : 1978-2853

E-ISSN : 2302-8890

\title{
PENGARUH KEPRIBADIAN PROAKTIF TERHADAP INTENSI KEWIRAUSAHAAN MAHASISWA : PENDIDIKAN KEWIRAUSAHAAN SEBAGAI VARIABEL MODERASI
}

\author{
Aurilia Triani Aryaningtyas ${ }^{1)}$, Dyah Palupiningtyas ${ }^{2)}$ \\ ${ }^{1,2)}$ Program Studi Manajemen, Sekolah Tinggi Ilmu Ekonomi Pariwisata Indonesia \\ (STIEPARI) Semarang \\ email: aurilia.ta@gmail.com
}

DOI : https://doi.org/10.24843/MATRIK:JMBK.2019.v13.i01.p02

\begin{abstract}
ABSTRAK
Penelitian ini menguji pengaruh kepribadian proaktif terhadap intensi kewirausahaan mahasiswa dengan pendidikan kewirausahaan sebagai variabel moderasi. Menggunakan teknik quota sampling, diambil sampel penelitian sejumlah 200 mahasiswa pada sepuluh perguruan tinggi di Semarang. Hasil menunjukkan kepribadian proaktif secara positif dan signifikan berpengaruh terhadap intensi kewirausahaan mahasiswa. Pendidikan kewirausahaan secara signifikan juga berpengaruh terhadap intensi kewirausahaan mahasiswa, sekaligus memoderasi hubungan kepribadian proaktif dan intensi kewirausahaan mahasiswa. Temuan ini konsisten dengan teori kepribadian kewirausahaan. Implikasi dari penelitian ini dapat digunakan bagi penyelenggara pendidikan tinggi dalam mendesain pola pendidikan kewirausahaan yang tepat dalam menumbuhkan intensi berwirausaha pada mahasiswanya.

Kata kunci: kepribadian proaktif, intensi kewirausahaan, pendidikan kewirausahaan.
\end{abstract}

\section{THE EFFECT OF PROACTIVE PERSONALITY ON STUDENTS' INTENTION TO BECOME ENTREPRENEURSHIP EDUCATION AS A MEDIATING VARIABLE}

\section{ABSTRACT}

This study examined the influence of proactive personality on the entrepreneurship intention of students with entrepreneurship education as the moderating variable. Using the quota sampling technique, a total of 200 students from ten universities in Semarang were selected as the research sample. The results showed that proactive personality positively and significantly influences student's entrepreneurship intention. Entrepreneurship education also has a significant influence on student's entrepreneurship intention, and at the same time moderates the relationship between proactive personality and the entrepreneurship intention of students. These findings are consistent with the theory of entrepreneurship personality. The implications of this research can be utilized by the providers of higher education in designing the right entrepreneurship education method to develop the student's entrepreneurship intention.

Keywords: proactive personality, entrepreneurship intention, entrepreneurship education

\section{PENDAHULUAN}

Salah satu tantangan berat yang dihadapi oleh bangsa Indonesia dewasa ini adalah adanya jumlah pengangguran yang sangat besar. Banyaknya angka pengangguran salah satunya juga disebabkan oleh minimnya jiwa wirausaha masyarakat (Ariamtisna, 2008). Tidak sedikit jumlah pengangguran yang memiliki latar belakang pendidikan tinggi. Laporan International Labor Organization (ILO) mencatat jumlah pengangguran terbuka pada tahun 2009 di Indonesia berjumlah 9.6 juta jiwa (7.6\%), dan 10\% diantaranya adalah sarjana (Nasrun, 2010).
Fenomena yang terjadi di Indonesia saat ini adalah sebagian besar lulusan perguruan tinggi masih berorientasi mencari kerja, bukan menciptakan lapangan kerja (Wijaya, 2007). Dari pertanyaan yang diajukan kepada mahasiswa di enam perguruan tinggi yang mewakili perguruan tinggi kelas bawah, menengah, dan atas tahun 2005 mengenai "Apa yang akan mereka lakukan setelah menyelesaikan pendidikan atau setelah memperoleh gelar sarjana?", sebagian besar $(76 \%)$ menjawab akan melamar bekerja dengan kata lain menjadi pegawai, $4 \%$ menjawab ingin berwirausaha, dan selebihnya 
menjawab bekerja sambil berwirausaha (Kasmir, 2006). Kondisi ini menunjukkan bahwa selama ini pendidikan di perguruan tinggi lebih banyak menghasilkan lulusan yang cakap sebagai pekerja berkualifikasi akademis tinggi, namun kurang memiliki jiwa wirausaha. Oleh karena itu, pihak perguruan tinggi bertanggung jawab dalam mendidik dan memberikan kemampuan berwirausaha kepada para lulusannya dan memberikan motivasi untuk berani memilih berwirausaha sebagai karir mereka. Pada akhirnya, lulusan perguruan tinggi diharapkan mampu menciptakan berbagai lapangan pekerjaan dengan berwirausaha.

Dalam upaya meningkatkan jumlah lulusan berjiwa wirausaha, maka mengungkapkan proses pembentukan dan penguatan niat untuk menjadi wirausaha menjadi cukup penting. Berdasarkan hal tersebut, maka peneliti ingin membahas tentang intensi kewirausahaan terutama dikaitkan dengan faktor-faktor yang mempengaruhinya. Beberapa penelitian telah melaporkan sejumlah anteseden intensi kewirausahaan seperti pendidikan (Kourilsky dan Walstad, 1998; Galloway, Kelly dan Keogh, 2006; Fatoki, 2014; Wibowo, 2016), maupun ciri-ciri kepribadian (Nishanta, 2008; Soumya dan Andrea, 2009; Rojuaniah, 2014).

Dalam penelitian psikologi organisasi, ciri-ciri kepribadian merupakan prediksi keberhasilan dalam berbagai bidang, salah satunya adalah bidang kewirausahaan. Beberapa penelitian juga telah membuktikan bahwa kepribadian proaktif menjadi prediktor utama dari intensi kewirausahaan seseorang. Crant (1996) menemukan adanya pengaruh positif antara kepribadian proaktif dengan intensi kewirausahaan. Temuan tersebut didukung oleh hasil penelitian Rauch dan Frese (2007), Mould (2013) dan Delle dan Amadu, (2015) yang menetapkan bahwa kepribadian proaktif berpengaruh positif terhadap intensi kewirausahaan.

Beberapa penelitian lain menguji proses moderasi yang menghubungkan antara kepribadian proaktif dan intensi kewirausahaan seperti harapan (Prieto, 2010), Efikasi diri (Prabhu, McGuire, Drost, dan Kwong, 2012), status pekerjaan dan level mahasiswa (Delle dan Amadu, 2015). Temuan menunjukkan bahwa harapan dan level mahasiswa tidak memoderasi hubungan antara kepribadian proaktif dan intensi kewirausahaan. Sedangkan status pekerjaan dan efikasi diri secara signifikan memoderasi hubungan antara kepribadian proaktif dan intensi kewirausahaan sehingga mahasiswa proaktif yang bekerja akan memiliki niat lebih tinggi menjadi wirausaha daripada mereka yang tidak bekerja.

Penelitian ini penting untuk dilakukan berdasarkan adanya beberapa kesenjangan yang ditemukan pada kajian penelitian sebelumnya. Pada penelitian-penelitian terdahulu lebih banyak mengkaji mengenai faktor-faktor yang mempengaruhi intensi kewirausahaan mahasiswa, di mana masih tampak variasi dari faktor-faktor yang mempengaruhi intensi kewirausahaan mahasiswa. Meski beberapa penelitian telah menguji proses moderasi hubungan antara kepribadian proaktif dengan intensi kewirausahaan mahasiswa, ada saran untuk mempertimbangkan kemungkinan mekanisme moderat lain yang terlibat dalam hubungan antara kepribadian proaktif dan intensi kewirausahaan seperti pendidikan kewirausahaan (Delle dan Amadu, 2015).

Berdasarkan hal tersebut, maka peneliti mencoba untuk mengkaji model proses moderasi yang menghubungkan kepribadian proaktif dan intensi kewirausahaan mahasiswa, sehingga dapat membuktikan suatu mekanisme apakah pendidikan kewirausahaan dapat mempengaruhi hubungan kepribadian proaktif (perilaku yang ditunjukkan oleh orang yang proaktif) untuk menumbuhkan intensi kewirausahaan mahasiswa. Variabel pendidikan kewirausahaan dapat dipertimbangkan sebagai variabel yang memoderasi hubungan antara kepribadian proaktif dengan niat kewirausahaan mahasiswa berdasarkan asumsi bahwa secara teori telah diyakini bahwa pembekalan pendidikan kewirausahaan dapat meningkatkan potensi seseorang untuk menjadi wirausahawan (Gerry, Susana, dan Nogueira, 2008). Pendidikan kewirausahaan juga terbukti secara efektif mengubah sikap personal dan persepsi individual terhadap kemampuan melaksanakan aktivitas entrepreneurial di kalangan mahasiswa (Wibowo, 2016).

Kewirausahaan adalah kemampuan kreatif dan inovatif yang dijadikan dasar, kiat, dan sumber daya untuk mencari peluang menuju sukses (Suryana, 2006). Hisrich dan Peters (2002), menjelaskan bahwa kewirausahaan adalah proses menciptakan sesuatu yang baru dan memiliki nilai dengan mengorbankan waktu dan tenaga, melakukan pengambilan risiko finansial, fisik, maupun sosial, serta menerima imbalan moneter serta kepuasan dan kebebasan pribadi. 
Intensi (niat) berwirausaha merupakan prediksi yang dapat dipercaya untuk mengukur perilaku kewirausahaan dan aktivitas kewirausahaan (Krueger, Reilly, dan Carsrud, 2000). Umumnya, intensi berwirausaha adalah keadaan berfikir yang secara langsung dan mengarahkan perilaku individu ke arah pengembangan dan implementasi konsep bisnis yang baru (Nazurdin, Ahmad, dan Lin, 2009). Dengan demikian, dapat disimpulkan bahwa intensi berwirausaha adalah niat seseorang untuk mendirikan suatu bisnis atau menerapkan konsep bisnis yang belum ada dengan sesuatu yang baru.

Menurut Choo dan Wong (2006), melalui intensi kewirausahaan dapat diprediksi individu mana saja yang akan menjadi wirausahawan. Seseorang dengan intensi untuk memulai suatu usaha akan memiliki kesiapan dan kemajuan yang lebih baik dalam usaha yang dijalankan dibandingkan seseorang tanpa intensi untuk memulai usaha. Manifestasi dari hal tersebut ditunjukkan dalam kemauan yang keras untuk memilih kewirausahaan sebagai pilihan pekerjaan dan mempersiapkan diri untuk mewujudkannya.

Pada dasarnya pembentukan jiwa kewirausahaan dipengaruhi oleh faktor internal dan eksternal (Priyanto, 2008). Faktor internal yang berasal dari dalam diri wirausahawan dapat berupa sifat-sifat personal, sikap, kemauan dan kemampuan individu yang dapat memberi kekuatan individu untuk berwirausaha. Sedangkan faktor eksternal berasal dari luar diri pelaku entrepreneur yang dapat berupa unsur dari lingkungan sekitar seperti lingkungan keluarga, lingkungan dunia usaha, lingkungan fisik, lingkungan sosial ekonomi dan lain-lain Suharti dan Sirine (2011).

Kepribadian proaktif menyiratkan kesediaan untuk terlibat dan mengambil inisiatif untuk mengidentifikasi dan memberikan kontribusi pada berbagai kegiatan dan situasi (Crant, 2000). Perilaku proaktif secara fundamental berbeda dari sifat-sifat afektif seperti kesejahteraan dan juga berbeda dari sifat-sifat kognitif seperti locus of control. Perilaku proaktif adalah kecenderungan untuk memulai dan mempertahankan tindakan yang langsung mengubah lingkungan sekitarnya (Bateman dan Crant, 1993). Meski demikian, kriteria utama untuk mengidentifikasi perilaku proaktif adalah bukan dalam peran atau ekstra peran, tetapi apakah seseorang mengantisipasi, merencanakan, dan mengupayakan untuk menciptakan hasil masa depan yang berdampak pada diri atau lingkungan (Grant dan Ashford, 2008; Parker et al., 2010)
Dalam perspektif interaksionis, pendekatan proaktif mempertimbangkan kemungkinan bahwa individu-individu menciptakan lingkungan mereka. Parker, Williams, dan Turner (2006) mengemukakan bahwa meskipun memiliki label dan dasar teoritis yang berbeda, konsep yang berhubungan dengan tingkat perilaku individu proaktif biasanya berfokus pada tindakan yang diprakarsai sendiri dan berorientasi masa depan yang bertujuan untuk mengubah dan memperbaiki situasi atau diri sendiri. Dalam literatur psikologi dan perilaku organisasi, perilaku dipengaruhi oleh faktor internal maupun eksternal. Situasi adalah merupakan faktor yang dapat mempengaruhi perilaku individu, demikian juga sebaliknya (Schneider, 1983). Hubungan timbal balik ada di antara orang, lingkungan, dan perilaku (Bandura, 1977). Oleh karena itu, individu dengan sengaja dan secara langsung dapat mengubah keadaan mereka saat ini sesuai dengan apa yang mereka inginkan. Dengan demikian, berdasarkan teori interaksionis dan perilaku yang terkait dengan kepribadian proaktif, masuk akal jika kepribadian proaktif dapat dijadikan sebagai salah satu faktor yang mempengaruhi intensi kewirausahaan. Beberapa penelitian juga telah membuktikan adanya pengaruh positif antara kepribadian proaktif dengan intensi kewirausahaan (Crant, 1996; Rauch dan Frese, 2007; Mould, 2013; Delle dan Amadu, 2015) $\mathrm{H}_{1}$ : Kepribadian proaktif berpengaruh positif dan signifikan terhadap intensi kewirausahaan mahasiswa.

Menurut Winardi (2008), kewirausahaan bukanlah sebuah sifat genetik. Ia merupakan sebuah ketrampilan yang dapat dipelajari. Pendidikan kewirausahaan menjadi faktor penting dalam menumbuhkan dan mengembangkan keinginan, jiwa dan prilaku berwirausaha dikalangan generasi muda karena pendidikan merupakan sumber sikap dan niat keseluruhan untuk menjadi wirausahawan sukses di masa depan (Fatoki, 2014). Pendidikan kewirausahaan merupakan usaha sadar yang dilakukan individu untuk menambah wawasan tentang kewirausahaan (Gerba, 2015). Menurut Akpan, Effiong, dan Ele (2012), pendidikan kewirausahaan adalah proses pembelajaran, melalui semua tingkat pendidikan.

Melalui pendidikan kewirausahaan yang diselenggarakan oleh perguruan tinggi, mahasiswa dibekali dengan pengetahuan yang bermakna agar dapat mendorong semangat mahasiswa untuk 
berwirausaha (Yohnson, 2003; Wu dan Wu, 2008). Dengan bekal pengetahuan kewirausahaan yang cukup, diharapkan mampu mengarahkan mahasiswa agar berani memulai usaha dan tidak bergantung pada lapangan pekerjaan yang jumlahnya terbatas.

Beberapa studi empiris memperlihatkan bahwa pendidikan kewirausahaan dapat memengaruhi perilaku kewirausahaan dan semangat berwirausaha pada kaum muda (Kourilsky dan Walstad, 1998; Galloway, Kelly dan Keogh, 2006). Penelitian yang dilakukan Gerry et al. (2008) menemukan bahwa pelatihan kewirausahaan terhadap 640 mahasiswa di Portugis berpengaruh secara signifikan dan positif terhadap niat mahasiswa untuk mendirikan usaha setelah mereka lulus dari perguruan tinggi. Hasil penelitian Bukirom, Indradi, Permana dan Martono (2014) dalam penelitian terhadap mahasiswa peserta HIPM, menemukan bahwa pendidikan kewirausahaan berpengaruh secara positif dan signifikan terhadap pembentukan jiwa entrepreneurship mahasiswa. Hal ini didukung penelitian yang dilakukan Aryaningtyas dan Palupiningyas (2017) yang menemukan bahwa pendidikan kewirausahaan berpengaruh positif dan signifikan terhadap niat kewirausahaan mahasiswa STIEPARI Semarang. Selain itu dari data 239 mahasiswa Fakultas Ekonomi dan Bisnis Universitas Indonesia menunjukkan pendidikan kewirausahaan terbukti secara efektif mengubah sikap personal dan persepsi individual terhadap kemampuan melaksanakan aktivitas entrepreneurial di kalangan mahasiswa strata 1 (Wibowo, 2016).

$\mathrm{H}_{2}$ : Pendidikan kewirausahaan berpengaruh positif dan signifikan terhadap intensi kewirausahaan mahasiswa.

$\mathrm{H}_{3}$ : Pendidikan kewirausahaan sebagai moderator hubungan antara kepribadian proaktif terhadap intensi kewirausahaan mahasiswa.

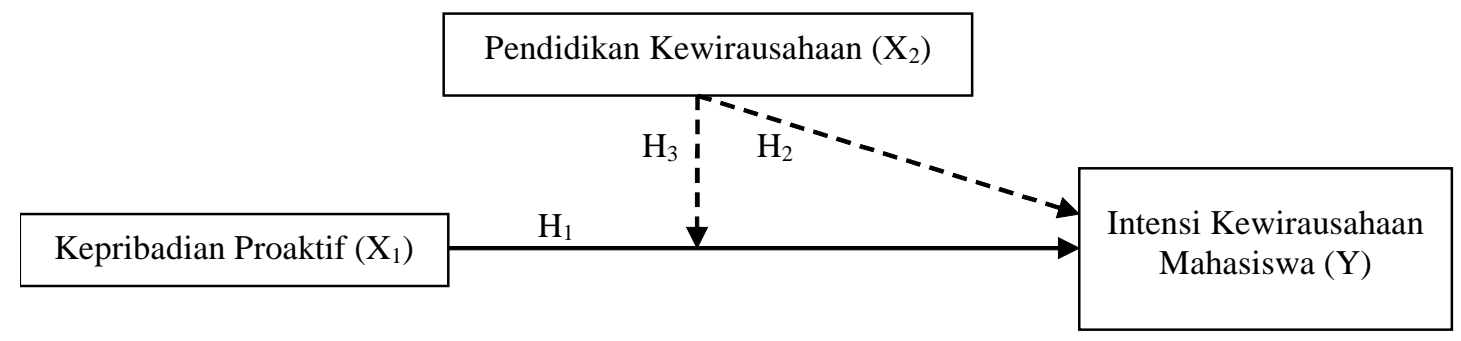

Gambar 1. Model Penelitian

\section{METODE PENELITIAN}

Penelitian ini merupakan jenis penelitian eksplanatori (explanatory research). Populasi dalam penelitian ini adalah mahasiswa Strata 1 reguler tingkat akhir pada Program Studi Manajemen pada sepuluh perguruan tinggi di Semarang yang terdiri dari empat Universitas, empat Sekolah Tinggi dan dua Politeknik. Teknik sampling yang digunakan adalah quota sampling, dimana peneliti mengambil sampel dari masing-masing perguruan tinggi dengan proporsi yang relatif sama (Sugiyono, 2001). Pengumpulan data dalam penelitian ini dilakukan dengan penyebaran kuesioner terstruktur kepada 200 mahasiswa di Semarang.

Penelitian ini menggunakan tiga variabel yaitu Kepribadian Proaktif (Proactive Personality), Pendidikan Kewirausahaan (Entrepreneurial Education), dan Intensi Kewirausahaan (Entrepreneurial intention). Pengukuran menggunakan skala Likert lima point $(1=$ sangat tidak setuju sampai 5 = sangat setuju).
Kepribadian proaktif diukur dengan 10 item pernyataan dari 17 item original yang dikembangkan oleh Bateman dan Crant (1993). Skala kepribadian proaktif telah digunakan dalam penelitian dengan 10 item pernyataan oleh Seibert, Crant, dan Kraimer (1999); Crant, 2000; Fuller et al. (2010). Seibert et al. (1999) menyebutkan bahwa penghapusan tujuh item tidak menghasilkan efek besar pada keandalan skala. Kesepuluh item diterjemahkan dalam bahasa Indonesia. Dalam pengukuran variabel pendidikan kewirausahaan, digunakan 3 item pernyataan terkait dengan pendidikan kewirausahaan yang pernah dijalani oleh responden dengan indikator yang telah digunakan dalam penelitian Budiarti (2012) dan Bukirom et al. (2014). Untuk mengukur variabel niat kewirausahaan (entrepreneurial intention), responden diminta menentukan tingkat ketertarikan mereka untuk mendirikan usaha sendiri setelah mereka lulus sarjana dengan 3 item pertanyaan yang diadopsi dari Gerry et al. (2008), yang menunjukkan tingkat intensi mereka untuk berwirausaha. Item diterjemahkan dalam bahasa Indonesia. Sebelum 
dilakukan analisis regresi, terlebih dahulu perlu dilakukan uji validitas dan reliabilitas. Uji validitas dalam penelitian ini menggunakan analisis butir (item) yakni dengan melakukan korelasi skor setiap item dengan skor total yang merupakan jumlah tiap skor butir. Hasil perhitungan $r_{x y}$ dikonsultasikan pada tabel $r_{x y}$ dengan taraf signifikan 5\%, jika $r_{\text {hitung }}>r$ tabel maka butir angket dikatakan valid. Untuk uji reliabilitas, suatu variabel dianggap reliabel jika nilai cronbach alpha Ã 0.60 (Ghozali, 2011).

Pengujian hipotesis menggunakan analisis regresi berjenjang, dengan uji interaksi yang sering disebut Moderated Regression Analysis (MRA), yaitu aplikasi khusus regresi berganda linear di mana persamaan regresinya mengandung unsur interaksi (perkalian dua atau lebih variabel independen) dengan rumus persamaan bertingkat sebagai berikut (Ghozali, 2011):

Tahap 1: $\mathrm{Y}=\beta_{1} \mathrm{X}_{1}$

Tahap 2: $Y=\beta_{1} X_{1}+\beta_{2} X_{2}$

Tahap 3: $Y=\beta_{1} X_{1}+\beta_{2} X_{2}+\beta_{3} X_{1} * X_{2}$

dimana:

$\mathrm{Y}=$ Variabel intensi kewirausahaan mahasiswa

$\mathrm{X}_{1} \quad=$ Variabel kepribadian proaktif

$\mathrm{X}_{2}=$ Variabel pendidikan kewirausahaan

$\mathrm{X}_{1} * \mathrm{X}_{2} \quad=$ interaksi antara $\mathrm{X}_{1}$ dan $\mathrm{X}_{2}$

$\beta_{1}, \beta_{2}, \beta_{3}=$ Koefisien variabel bebas

Variabel perkalian antara $\mathrm{X}_{1}$ dan $\mathrm{X}_{2}$ merupakan variabel moderasi oleh karena menggambarkan pengaruh moderasi variabel $\mathrm{X}_{2}$ terhadap hubungan $X_{1}$ dan $Y$. Sedangkan variabel $X_{1}$ dan $X_{2}$ adalah merupakan pengaruh langsung dari variabel $X_{1}$ dan $\mathrm{X}_{2}$ terhadap $\mathrm{Y}$.

\section{HASIL DAN PEMBAHASAN}

Karakteristik responden berdasarkan jenis kelamin menunjukkan bahwa jumlah responden yang berjenis kelamin laki-laki sebanyak 117 responden $(58,5 \%)$, sedangkan yang berjenis kelamin perempuan sebanyak 83 responden $(41,5 \%)$. Karakteristik responden berdasarkan umur menggambarkan bahwa responden didominasi oleh mahasiswa berusia 20-23 tahun yang berjumlah 144 responden (72\%). Berdasarkan pekerjaan orang tua, responden dikelompokkan dalam 2 golongan yaitu berwirausaha dan tidak berwirausaha. Sebagian besar responden memiliki orang tua tidak berwirausaha sebanyak 136 responden $(68 \%)$ dan sisanya $32 \%$ memiliki orang tua berwirausaha. Hal ini menggambarkan bahwa responden sebagian besar berasal dari latar belakang keluarga bukan wirausahawan. Adapun karakteristik responden berdasarkan pengalaman berwirausaha menunjukkan bahwa sebagian besar responden memiliki pengalaman berwirausaha sebanyak 132 responden (66\%) dan sisanya tidak memiliki pengalaman berwirausaha 68 responden $(34 \%)$. Hal ini menggambarkan bahwa responden sebagian besar sudah mempunyai pengalaman berwirausaha.

Ringkasan statistik deskriptif dari masingmasing variabel disajikan sebagai berikut:

Tabel 1. Statistik Deskriptif

\begin{tabular}{lccc}
\hline & N & Minimum & Maksimum \\
\hline X1 & 200 & 2.70 & 5.00 \\
$\mathbf{X 2}$ & 200 & 2.33 & 5.00 \\
Y & 200 & 3.33 & 5.00 \\
Valid N (listwise) & 200 & & \\
\hline
\end{tabular}

Sumber: Data primer, diolah. 2017

Total rata-rata skor tiap variabel di atas 4,00 menunjukkan bahwa tingkat kepribadian proaktif, pendidikan kewirausahaan, dan intensi kewirausahaan mahasiswa di Semarang termasuk dalam kategori tinggi.

Uji validitas digunakan untuk mengukur sejauhmana ketepatan dan kecermatan suatu alat ukur (instrument penelitian) untuk melakukan fungsi ukurnya. Uji reliabilitas diperlukan untuk mengetahui konsistensi suatu alat ukur di dalam mengukur gejala-gejala yang sama terhadap masing-masing butir pertanyaan kuesioner. 
Tabel 2. Hasil Uji Validitas dan Reliabilitas

\begin{tabular}{|c|c|c|}
\hline Variabel & r hitung & $\begin{array}{c}\text { Reliabilitas } \\
\text { (Cronbach } \\
\text { Alpha) }\end{array}$ \\
\hline Kepribadian Proaktif (Proactive Personality) & & 0.785 \\
\hline 1. Saya selalu mencari cara baru untuk meningkatkan hidup & 0.498 & \\
\hline 2. Saya selalu membuat perubahan yang konstruktif & 0.701 & \\
\hline 3. Saya selalu merubah ide menjadi kenyataan & 0.705 & \\
\hline 4. Saya selalu memperbaiki sesuatu & 0.575 & \\
\hline 5. Saya selalu membuat segala kemungkinan menjadi kenyataan & 0.717 & \\
\hline 6. Saya selalu memperjuangkan ide-ide & 0.682 & \\
\hline 7. Saya memiliki keunggulan dalam mengidentifikasi peluang & 0.516 & \\
\hline 8. Saya selalu mencari cara yang lebih baik dalam melakukan sesuatu & 0.677 & \\
\hline 9. Saya memiliki kemampuan mewujudkan ide menjadi suatu kenyataan & 0.568 & \\
\hline 10. Saya memiliki kemampuan melihat kesempatan & 0.369 & \\
\hline Pendidikan Kewirausahaan (Entrepreneurial Education) & & 0.747 \\
\hline $\begin{array}{l}\text { 1. Dalam diri saya tumbuh keinginan berwirausaha setelah menempuh mata } \\
\text { kuliah kewirausahaan }\end{array}$ & 0.857 & \\
\hline $\begin{array}{l}\text { 2. Ilmu dan wawasan dalam bidang wirausaha saya bertambah setelah } \\
\text { menempuh mata kuliah kewirausahaan }\end{array}$ & 0.805 & \\
\hline $\begin{array}{l}\text { 3. Dalam diri saya tumbuh kesadaran adanya peluang bisnis setelah } \\
\text { menempuh mata kuliah kewirausahaan }\end{array}$ & 0.784 & \\
\hline Intensi Kewirausahaan (Entrepreneurial Intention) & & 0.627 \\
\hline 1. Saya akan memilih karir sebagai wirausahawan setelah lulus nanti & 0.755 & \\
\hline $\begin{array}{l}\text { 2. Saya lebih suka menjadi wirausahawan dalam usaha saya sendiri daripada } \\
\text { menjadi karyawan suatu perusahaan/ organisasi }\end{array}$ & 0.753 & \\
\hline $\begin{array}{l}\text { 3. Saya memperkirakan dapat memulai usaha saya sendiri (berwirausaha) } \\
\text { dalam 1-3 tahun kedepan }\end{array}$ & 0.774 & \\
\hline
\end{tabular}

Sumber: Data primer, diolah. 2017

Hasil uji validitas menunjukkan semua instrumen variabel bernilai positif dan lebih besar dari $r$ tabel (0.138). Koefisien alpha dari semua variabel menunjukkan alpha di atas 0,6. Ini berarti semua instrumen adalah valid dan reliabel dan dapat digunakan untuk proses pengolahan data selanjutnya.Hasil pengujian hipotesis menggunakan analisis regresi berjenjang, dengan uji interaksi yang sering disebut Moderated Regression Analysis (MRA) adalah sebagai berikut

Tabel 3. Rangkuman Perubahan Model Regresi Berjenjang

\begin{tabular}{|c|c|c|c|}
\hline & Tahap 1 (ß) & Tahap 2 ( $\beta$ ) & Tahap 3 ( $\beta$ ) \\
\hline $\mathrm{X}_{1}$ & $.678 * *$ & $.611 * *$ & $-.750 *$ \\
\hline $\mathrm{X}_{2}$ & & $.136^{*}$ & $-1.941 * *$ \\
\hline $\mathrm{X}_{1} * \mathrm{X}_{2}$ & & & $2.996 * *$ \\
\hline $\mathrm{R}^{2}$ & .459 & .474 & .524 \\
\hline $\mathrm{R}^{2}$ & .459 & .014 & .050 \\
\hline $\mathrm{F}$ & $168.326 * *$ & $88.610 * *$ & $71.935 * *$ \\
\hline
\end{tabular}

* signifikan pada level $0.05, * *$ signifikan pada level 0.01

Dari tabel 2 diperoleh persamaan regresi berganda sebagai berikut :

Tahap 1: $\mathrm{Y}=0,678 \mathrm{X}_{1}$

Tahap 2: $Y=0,611 X_{1}+0,136 X_{2} \ldots \ldots \ldots \ldots \ldots \ldots . . .(5)$

Tahap 3: $Y=-0,750 X_{1}-1,941 X_{2}+2,996 X_{1} * X_{2}$. (6)

Pada persamaan (4), koefisien regresi sebesar 0,678 dan nilai t hitung sebesar 12,974 > t tabel sebesar 1,97 dan signifikansi 0,000 menunjukkan bahwa kepribadian proaktif $\left(\mathrm{X}_{1}\right)$ berpengaruh positif dan signifikan terhadap intensi kewirausahaan mahasiswa (Y), dengan demikian hipotesis 1 dapat diterima.

Pada persamaan (5), koefisien regresi sebesar 0,136 dan nilai $\mathrm{t}$ hitung sebesar 2,295 > t tabel 
sebesar 1,97 dan signifikansi 0,023 menunjukkan bahwa pendidikan kewirausahaan $\left(\mathrm{X}_{2}\right)$ berpengaruh positif dan signifikan terhadap intensi kewirausahaan mahasiswa, dengan demikian hipotesis 2 dapat diterima.

Uji moderasi terdapat pada persamaan (6) dimana dalam regresi sudah dimasukkan variabel product moderasi $\left(\mathrm{X}_{1} * \mathrm{X}_{2}\right)$ selain variabel $\mathrm{X}_{1}$ dan $\mathrm{X}_{2}$ untuk mempengaruhi intensi kewirausahaan (Y). Berdasarkan persamaan di atas, hasil pengujian secara parsial menunjukkan variabel product moderasi $\left(\mathrm{X}_{1} * \mathrm{X}_{2}\right)$ memberikan nilai koefisien sebesar 2,996 dengan signifikansi 0,000. Hal ini berarti bahwa variabel $\mathrm{X}_{1} * \mathrm{X}_{2}$ berpengaruh signifikan terhadap Y. Selanjutnya dapat disimpulkan bahwa variabel pendidikan kewirausahaan terbukti sebagai variabel moderasi antara kepribadian proaktif terhadap intensi kewirausahaan mahasiswa. Suatu variabel dikatakan moderasi jika interaksinya antara variabel independen menunjukkan nilai yang signifikan, dengan demikian hipotesis 3 dapat diterima

Bukti empiris dalam penelitian ini menemukan bahwa kepribadian proaktif secara signifikan dan positif mempengaruhi intensi kewirausahaan. Temuan ini sesuai dengan temuan dalam penelitian sebelumnya oleh Crant (1996), Rauch dan Frese (2007), Mould (2013), dan Delle dan Amadu (2015) yang menetapkan bahwa kepribadian proaktif berhubungan positif dengan intensi kewirausahaan. Crant (1996) menjelaskan bahwa orang dengan kepribadian yang sangat proaktif akan selalu ingin memengaruhi lingkungannya. Bandura (1977) dan (Schneider (1983) menyatakan bahwa pendekatan proaktif mempertimbangkan kemungkinan bahwa individu-individu menciptakan lingkungan mereka.

Menurut definisi, kewirausahaan membutuhkan perilaku proaktif seperti menemukan peluang serta keberanian bertindak untuk membangun bisnis baru (Suryana, 2006; Hisrich dan Peters, 2002). Oleh karena itu orang dengan kepribadian proaktif mempunyai kemungkinan lebih tertarik untuk menjadi pengusaha dan bertanggung jawab atas bisnis mereka sendiri daripada menjadi karyawan dan harus melapor ke manajemen. Sikap proaktif inilah yang memungkinkan individu tersebut memiliki intensi untuk memiliki usaha sendiri dibandingkan menggantungkan pada lapangan pekerjaan yang jumlahnya terbatas.

Pendekatan proaktif juga dijelaskan oleh Crant (1996) yang berakar pada sudut pandang interaksionis di mana ada hubungan timbal balik antara orang, lingkungan, dan perilaku (Bandura, 1977). Individu dengan ciri kepribadian yang proaktif memiliki keterampilan untuk secara aktif mengubah lingkungannya serta menunjukkan inisiatif untuk bertahan sampai perubahan terjadi (Bateman dan Crant, 1993). Oleh karena itu, dapat diantisipasi bahwa individu yang proaktif akan cenderung menciptakannya lingkungan untuk diri mereka sendiri yang lebih kondusif untuk memenuhi niat mereka berwirausaha.

Berdasarkan temuan tersebut, dapat disimpulkan bahwa mahasiswa dengan kepribadian proaktif yang tinggi akan memiliki intensi kewirausahaan yang tinggi pula. Oleh karena itu perguruan tinggi dapat mempertimbangkan kepribadian proaktif mahasiswa sebagai salah satu faktor yang dapat digunakan untuk meningkatkan intensi kewirausahaan sehingga diharapkan perannya dalam mendorong pertumbuhan kewirausahaan.

Pendidikan kewirausahaan ditemukan secara positif dan signifikan mempengaruhi intensi kewirausahaan mahasiswa. Temuan ini mendukung penelitian Gerry et al. (2008) yang menemukan bahwa pelatihan kewirausahaan berpengaruh secara signifikan dan positif terhadap niat mahasiswa untuk mendirikan usaha setelah mereka lulus dari perguruan tinggi. Bukirom et al. (2014) juga menemukan bahwa pendidikan kewirausahaan berpengaruh secara positif dan signifikan terhadap pembentukan jiwa kewirausahaan mahasiswa.

Pendidikan kewirausahaan merupakan faktor essensial untuk menumbuhkan niat berwirausaha karena merupakan sumber sikap dan niat keseluruhan untuk menjadi wirausaha, dimana melalui pendidikan kewirausahaan potensi yang dimiliki mahasiswa dapat digali dan dikembangkan (Adnyana dan Purnami, 2016). Fatoki (2014) berpendapat pendidikan kewirausahaan menjadi faktor terpenting dalam menumbuhkan dan mengembangkan keinginan, jiwa dan perilaku berwirausaha dikalangan generasi muda karena pendidikan merupakan sumber sikap dan niat keseluruhan untuk menjadi wirausahawan. Hal ini didukung oleh hasil penelitian Aryaningtyas dan Palupiningyas (2017) yang menemukan bahwa pendidikan kewirausahaan berpengaruh positif signifikan terhadap niat kewirausahaan mahasiswa.

Melalui pendidikan kewirausahaan yang diselenggarakan oleh perguruan tinggi, mahasiswa dibekali dengan pengetahuan yang bermakna agar 
dapat mendorong semangat mahasiswa untuk berwirausaha (Yohnson 2003, Wu dan Wu, 2008). Dengan bekal pengetahuan kewirausahaan yang cukup, diharapkan mampu mengarahkan mahasiswa agar berani memulai usaha dan tidak bergantung pada lapangan pekerjaan yang jumlahnya terbatas. Oleh karena itu perguruan tinggi dapat lebih mengembangkan pendidikan kewirausahaan sebagai bekal bagi mahasiswa untuk berwirausaha setelah lulus dari perguruan tinggi. Dengan kemampuan yang dimiliki diharapkan potensi mahasiswa untuk menjadi wirausahawan semakin tinggi.

Selanjutnya pendidikan kewirausahaan juga ditemukan memoderasi pengaruh kepribadian proaktif dengan intensi kewirausahaan mahasiswa. Mahasiswa dengan perilaku proaktif mempunyai kecenderungan untuk memulai dan mempertahankan tindakan yang langsung mengubah lingkungan sekitarnya (Bateman dan Crant, 1993). Mahasiswa proaktif cenderung memiliki keunggulan dalam mengidentifikasi peluang, mencari cara yang lebih baik dalam melakukan sesuatu, kemampuan mewujudkan ide menjadi suatu kenyataan, dan kemampuan melihat kesempatan (Seibert et al., 1999; Crant, 2000; Fuller dan Cox, 2010). Pendidikan kewirausahaan relatif berhasil membuka pemikiran mahasiswa dalam melihat peluang-peluang bisnis dan besarnya keuntungan yang mungkin dapat diperoleh melalui sebuah aktivitas entrepreneurial serta membuka berbagai alternatif model bisnis yang memungkinkan pelaku wirausaha untuk dapat menjalankan bisnis baru.

Pendidikan kewirausahaan terbukti secara efektif mampu mengubah sikap personal dan penilaian individu terhadap kemampuannya sendiri menjadi lebih kondusif untuk berniat sebagai pengusaha mandiri. (Wibowo, 2016). Hal ini karena pendidikan kewirausahaan mampu mengubah persepsi terhadap kemampuan sebagai pengusaha. Setidaknya mereka yang telah lulus kuliah kewirausahaan memiliki kepercayaan diri yang lebih tinggi dibandingkan yang belum mengambil mata kuliah tersebut (Wibowo, 2016; Fayolle dan Gaily, 2014).

Hal penting yang perlu diperhatikan di sini, bahwa mahasiswa proaktif menyiratkan kesediaan untuk terlibat dan mengambil inisiatif untuk mengidentifikasi dan memberikan kontribusi pada berbagai kegiatan dan situasi (Crant, 2000). Dengan bekal pengetahuan kewirausahaan yang cukup, diharapkan mampu mengarahkan sikap proaktif mahasiswa agar berani memulai usaha dan tidak bergantung pada lapangan pekerjaan yang jumlahnya terbatas. Oleh karena itu perguruan tinggi dapat lebih mengembangkan pendidikan kewirausahaan sebagai bekal bagi mahasiswa untuk berwirausaha setelah lulus dari perguruan tinggi. Selain itu juga memberi kesempatan yang luas bagi mahasiswa proaktif untuk terlibat dan mengambil inisiatif serta memberikan kontribusi pada berbagai kegiatan dalam lingkungan perguruan tinggi agar dapat meningkatkan intensi kewirausahaannya. Dengan kemampuan yang dimiliki diharapkan potensi mahasiswa untuk menjadi wirausahawan semakin tinggi.

\section{SIMPULAN DAN SARAN}

Berdasarkan hasil penelitian yang diperoleh, maka terdapat beberapa hal yang dapat disimpulkan dalam penelitian ini sesuai dengan tujuan yang telah ditetapkan, yaitu terbukti bahwa kepribadian proaktif berpengaruh positif dan signifikan terhadap intensi kewirausahaan mahasiswa, pendidikan kewirausahaan juga ditemukan sebagai variabel yang berpengaruh langsung terhadap intensi kewirausahaan mahasiswa, dan sekaligus dapat menjadi variabel moderasi pengaruh kepribadian proaktif dan intensi kewirausahaan mahasiswa.

Dengan temuan bahwa kepribadian proaktif merupakan variabel yang berpengaruh terhadap intensi kewirausahaan mahasiswa, maka mahasiswa harus belajar dan terlibat dalam perilaku proaktif sehingga mereka akan mampu mengambil inisiatif seperti memulai bisnis mereka sendiri atau menghasilkan ide bisnis. Mahasiswa proaktif memiliki energi, fokus dan semangat untuk menjadi pengusaha sukses, oleh karena itu perguruan tinggi di Indonesia dapat mempertimbangkan kepribadian proaktif salah satu faktor yang dapat digunakan untuk meningkatkan intensi kewirausahaan dan selanjutnya diharapkan dapat mengurangi tingkat pengangguran di Indonesia.

Temuan lain dalam penelitian ini adalah bahwa pendidikan kewirausahaan ditemukan sebagai variabel yang secara langsung mempengaruhi intensi kewirausahaan mahasiswa. Selanjutnya pendidikan kewirausahaan juga memoderasi pengaruh kepribadian proaktif dengan intensi kewirausahaan mahasiswa. Oleh karena itu perguruan tinggi dapat lebih mengembangkan pendidikan kewirausahaan sebagai bekal bagi mahasiswa untuk berwirausaha setelah lulus dari perguruan tinggi. Dengan kemampuan yang dimiliki diharapkan potensi 
mahasiswa untuk menjadi wirausahawan semakin tinggi.

Hasil penelitian ini juga memperkuat pentingnya perguruan tinggi dalam memberikan pembinaan serta mengarahkan sikap proaktif mahasiswa dengan memperkuat pendidikan kewirausahaan bagi mahasiswanya. Perguruan tinggi dapat menuai keuntungan dari inisiatif pribadi mahasiswa dengan memberi kesempatan yang luas serta menciptakan atmosfir yang mendukung bagi mahasiswa proaktif untuk terlibat dan mengambil inisiatif serta memberikan kontribusi pada berbagai kegiatan yang akan meningkatkan intensi kewirausahaannya. Dengan memperoleh pendidikan kewirausahaan, dapat menyebabkan mahasiswa makin termotivasi untuk menjadi wirausahawan dan sekaligus memungkinkan untuk dapat menciptakan lapangan kerja.

Penelitian yang telah dilakukan ini masih memiliki kelemahan dikarenakan adanya beberapa keterbatasan, antara lain karena penelitian ini hanya dilakukan pada lokasi penelitian yang terbatas, yaitu mahasiswa di Semarang. Meskipun responden berasal dari berberapa perguruan tinggi, namun kiranya hasil penelitian ini tidak dapat digeneralisasikan dan harus diinterpretasikan secara hati-hati. Adanya perbedaan karakteristik profil responden seperti jenis kelamin, umur, pekerjaan orang tua dan pengalaman berwirausaha yang belum dielaborasi dan dianalisis lebih jauh merupakan kelemahan tersendiri dari penelitian ini.

Penelitian mendatang dapat melakukan beberapa pengembangan dari penelitian ini, misalnya dapat dilakukan pengujian ulang model yang sama pada sampel yang berbeda untuk mengetahui konsistensi hasil penelitian ini. Untuk menambah kontribusi teoretis, dapat dilakukan penyempurnaan model dengan menambahkan variabel-variabel lain yang dirasa relevan pada kelompok variabel bebas maupun variabel tergantungnya serta menambah analisis mengenai perbedaan karakteristik profil responden seperti jenis kelamin, umur, pekerjaan orang tua dan pengalaman berwirausaha. Dapat juga dicoba menggunakan metode penelitian yang berbeda untuk memperoleh pemahaman yang lebih baik dan hasil yang lebih akurat.

\section{REFERENSI}

Adnyana, I Gusti Lanang Agung dan Purnami, Ni Made. (2016). Pengaruh Pendidikan Kewirausahaan, Self Efficacy dan Locus of Control Pada Niat
Berwirausaha. E-Jurnal Manajemen Unud, 5(2), 1160-1188.

Akpan EI, Effiong SA, dan Ele AA. (201)2. Entrepreneurship Education Policy: An Intervention Strategy For Economic Development In Nigeria Bus. Entrepreneurship J, 1(1), 101110

Ariamtisna, L. (2008). Studi kewirausahaan pada mahasiswa Universitas Brawijaya. Jurnal Eksekutif, 5, 281-292

Aryaningtyas, A.T., dan Palupiningtyas, D. (2017). Pengaruh Pendidikan Kewirausahaan dan Dukungan Akademik Terhadap Niat Kewirausahaan Mahasiswa (Studi Pada Mahasiswa STIEPARI Semarang), Jurnal Ilmiah Manajemen dan Bisnis, 18(1), 1-11.

Bandura, Albert. (1977). Social Learning Theory. Englewood Cliffs, N.J.: Prentice-Hall.

Bateman, Thomas S, and J. Michael Crant. (1993). The Proactive Component of Organizational Behavior. Journal of Organizational Behavior, 14(2), 103-118.

Budiarti, M. (2012). Analisis Pengaruh Pendidikan Kewirausahaan Terhadap Niat Kewirausahaan Mahasiswa Studi Kasus Pada Mahasiswa Program Ekstensi Fakultas Ekonomi Universitas Indonesia. Skripsi Sarjana. Jurusan Manajemen pada Fakultas Ekonomi Universitas Indonesia, Salemba.

Bukirom, Indradi,H., Permana, A., dan Martono. (2014). Pengaruh Pendidikan Berwirausaha dan Motivasi Berwirausaha terhadap Pembentukan Jiwa Berwirausaha Mahasiswa. Media Ekonomi dan Manajemen, 29(2), 144-151.

Choo, S., dan Wong, M. (2006). Entrepreneurial Intention: Triggers and Barriers to New Venture Creations in Singapore. Singapore Management Review, 28(2), 47-64.

Crant, J. M. (2000). Proactive Behavior in Organizations. Journal of Management, 26, 435-462.

Crant, M. J. (1996). The Proactive Personality Scale as a Predictor of Entrepreneurial Intentions. Journal of Small Business Management, 34(3), 42- 49.

Delle, Eric and Amadu, Ibrahim Monipaak. (2015). Proactive Personality and Entrepreneurial Intention: Employment Status and Student Level as Moderators. International Journal of Small Business and Entrepreneurship Research, 3(4), 1-13. 
Fatoki, Olawale. (2014). The Entrepreneurial Intention of Undergraduate Students in South Africa: The Influences of Entrepreneurship Education and Previous Work Experience. Mediterranean Journal of Social Sciences, 5(7), 294-299.

Fayolle, A., Gailly, B., Lassas, N. (2005). Capturing Variations in Attitudes and Intentions: A Longitudinal Study to Asses the Pedagogical Effectiveness of Entrepreneurial Programmes. The European Institution for Lifelong Learning

Fuller, Jerry Bryan Jr. Hester, Kim dan Cox, Susie S. (2010). Proactive Personality and Job Performance: Exploring Job Autonomy as a Moderator. Journal of Managerial Issues, 22(1). Galloway. L, Kelly. S. dan Keogh. W. (2006). Identifying Entrepreneurial Potential in Students. Working Paper, No. 006, National Council for Graduate Entrepreneurship.

Gerba, Dugassa Tessema. (2012). Impact of entrepreneurship education on entrepreneurial intentions of business and engineering students in Ethiopia. Journal of Economic and Management Studies, 3(2), 258-277.

Gerry. C, Susana. C. dan Nogueira. F. (2008). Tracking Student Entrepreneurial Potential: Personal Attributes and the Propensity for Business Start-Ups after Graduation in a Portuguese University. International Research Journal Problems and Perspectives in Management, 6(4), 45-53.

Ghozali, Imam. (2011). Aplikasi Analisis Multivariate Dengan Program SPSS. Edisi 5. Semarang: BP Universitas Diponegoro

Grant, A. M., dan Ashford, S. J. (2008). The Dynamics of Proactivity at Work: Lessons from Feedback-Seeking and Organizational Citizenship Behavior Research. In B. M. Staw dan R. M. Sutton (Eds.), Research in Organizational Behavior, 28, 3-34. Amsterdam: Elsevier.

Hisrich, Robert D. dan Peters, Michael P. (2002). Entrepreneurs (5th ed). Boston: McGraw-Hill.

Kasmir. (2006). Kewirausahaan. Jakarta: PT Raja Grafindo Persada.

Kourilsky, M. L. dan Walstad, W. B. (1998). Entrepreneurship and Female Youth: Knowledge, Attitudes, Gender Differences and Educational Practices. Journal of Business Venturing, 13(1), 77-88.
Krueger, N. F. (1993). The Impact of Prior Entrepreneurial Exposure on Perceptions of New Venture Feasibility and Desirability. Entrepreneurship Theory and Practice, 18(1), 5-23.

Mould, C. (2013). Do Personality Traits Predict Entrepreneurial Intention and Performance?. Dissertation. Faculty of Commerce-University of Cape Town.

Nasrun, M. A. (2010). Mengapa Banyak Sarjana yang Menganggur? Suara Merdeka, 25 September.

Nazurdin, A. M., Ahmad, N. H., dan Lin, C. E. (2009). Examining a Model of Entrepreneurial Intention Among Malaysian Using SEM Procedure. European Journal of Scientific Research, 33(2), 365-373

Nishanta, B. (2008). Influence of Personality Traits and Socio-demographic Background of Undergra-duate Students on Motivation for Entrepre-neurial Career: The Case of Srilanka. Paper was presented at the Euro-Asia Management Studies Association (EAMSA) Conference, Japan.

Parker, Sharon K. (2010). Making Things Happen: A Modelof Proactive Motivation. Journal of Management, 20(10), 1-30.

Parker, S. K., Williams, H. M., dan Turner, N. (2006). Modeling the Antecedents of Proactive Behavior at Work. Journal of Applied Psychology, 91, 636-652.

Prabhu, Veena P., Stephen J. McGuire, Ellen A. Drost., dan Kern K. Kwong. (2012) Proactive personality and entrepreneurial intent: Is entrepreneurial self efficacy a mediator or moderator?, International Journal of Entrepreneurial Behavior dan Research, 18(5), 559-586

Prieto, Leon C. (2010). The influence of proactive personality on social entrepreneurial intentions among African-American and Hispanic undergraduate students: the moderating role of hope. Dissertation. Louisiana State University and Agricultural and Mechanical College.

Priyanto S.H. (2008). Di dalam Jiwa ada Jiwa: The Backbone and the Social Construction of Entrepreneurships. Pidato Pengukuhan Guru Besar Universitas Kristen Satya Wacana.

Rauch, A., dan Frese, M. (2007). Let's put the person back into entrepreneurship research: A meta-analysis on the relationship between business owners ' personality traits, business 
creation, and success. European Journal of Work and Organizational Psychology, 16(4), 353-385.

Rojuaniah. (2014). Pengaruh Faktor Demografi dan Karakteristik Pribadi Terhadap Keinginan Berwirausaha Mahasiswa Universitas Esa Unggul. Forum Ilmiah, Fakultas Ekonomi Universitas Esa Unggul Jakarta, 11(1), 137-146.

Schneider, Benjamin. (1983). Interactional Psychology and Organizational Behavior, Research in Organizational Behavior. Ed. Larry L. Cummings and Barry M. Staw. Greenwich, Conn.: JAI Press.

Seibert, S. E., Crant, J. M., dan Kraimer, M. L. (1999). Proactive Personality and Career Success. Journal of Applied Psychology, 84, 416-427.

Soumya, S. and Andrea, A. (2009). Identifying the Effect of Psychological Variables on Entrepreneurial Intentions. DSM Business Review, 1(2), 61-84.

Sugiyono. (2001). Statistika untuk Penelitian. Bandung: Alfabeta.

Suharti, Lieli dan Sirine, H. (2011). Faktor-Faktor yang Berpengaruh Terhadap Niat Kewirausahaan (Entrepreneurial Intention) (Studi Terhadap
Mahasiswa Universitas Kristen Satya Wacana, Salatiga). Jurnal Manajemen dan Kewirausahaan, 13(2), 124-134

Suryana. (2006). Kewirausahaan: Pedoman praktis: Kiat dan Proses Menuju Sukses. Edisi 3. Jakarta: Salemba Empat.

Wibowo, Buddi. (2016). Pemodelan Determinan Niat Berwirausaha dan Efek Pengaruh Edukasi Kewirausahaan di Kalangan Mahasiswa. MIX: Jurnal Ilmiah Manajemen, I (2), 152 -170.

Wijaya, Tony. (2007). "Hubungan Adversity Intelligence dengan Intensi Berwirausaha (Sudi Empiris pada Siswa SMKN 7 Yogyakarta)". Jurnal Manajemen dan Kewirausahaan, 9, 117-127.

Winardi, J. (2008). Entrepreneur dan entrepreneurship. Jakarta: Kencana

$\mathrm{Wu}, \mathrm{S}$. dan $\mathrm{Wu}, \mathrm{L}$. (2008). The Impact of Higher Education on Entrepreneurial Intentions of University Students in China. Journal of Small Business and Enterprise Development, 15(4), 752-774.

Yohnson. (2003). Peranan Universitas dalam Memotivasi Sarjana Menjadi Young Entrepreneurs. Jurnal Manajemen dan Kewirausahaan, 5(2), 97-111. 